\title{
Weed Management Guide for Florida Lawns ${ }^{1}$
}

\author{
J.Bryan Unruh, Ramon G. Leon, Barry J. Brecke, and Laurie E. Trenholm²
}

Weeds can be defined as unwanted plants or plants growing out of place. Proper identification and some understanding of how and why weeds are present in a lawn are important when selecting the best control strategy. Knowing whether or not weeds were previously present in a particular area also helps homeowners prepare control measures in the future. Weed control should be a carefully planned and coordinated program.

\section{Weed Types}

Knowing a weed's growth habit is important when developing an effective weed management program.

\section{Broadleaves}

Broadleaves, or dicotyledonous plants, have two cotyledons (seed leaves) when the weed seed germinates. Their true leaves have net-like veins and usually have showy flowers. Examples include clovers, lespedeza, plantain, henbit, chickweed, Florida pusley, beggarweed, and matchweed.

\section{Grasses}

Grasses are monocotyledonous plants that have only one cotyledon, or seed leaf, present when seedlings emerge from the soil. Grasses have hollow, rounded stems with nodes (joints) and parallel veins in their true leaves. Examples include crabgrass, goosegrass, crowfootgrass, dallisgrass, bullgrass, annual bluegrass, alexandergrass, cogongrass, torpedograss, and smutgrass.

\section{Sedges/Rushes}

Sedges have triangular-shaped, solid stems, while rush stems are round and solid. Both sedges and rushes favor a moist habitat. Economically important members include yellow and purple nutsedge and, to some degree, globe, Texas, annual, and water sedge, plus path and beak rush and perennial kyllinga.

Weeds are also classified based on their life cycles, which is the period between seed germination and plant death.

\section{Annuals}

Annual weeds complete their life cycles in one growing season. Summer annuals complete their life cycles from spring to fall. Winter annuals complete their life cycles from fall to spring. Summer annual grasses, as a class, are generally the most troublesome weeds in turf.

\section{Biennials}

Weeds that complete their life cycles in two growing seasons are called biennials. Most biennial plants show only vegetative growth during the first growing season, and flowering occurs during the second growing season.

1. This document is ENH884, one of a series of the Environmental Horticulture Department, UF/IFAS Extension. Original publication date March 2003. Revised July 2013. Visit the EDIS website at http://edis.ifas.ufl.edu.

2. J. Bryan Unruh, professor and associate center director, West Florida Research and Education Center; Ramon G. Leon, assistant professor, West Florida Research and Education Center; Barry J. Brecke, professor Emeritus and interim center cirector, West Florida Research and Education Center; and Laurie E. Trenholm, professor, Environmental Horticulture Department, UF/IFAS Extension, Gainesville, FL 32611.

The use of trade names in this publication is solely for the purpose of providing specific information. UF/IFAS does not guarantee or warranty the products named, and references to them in this publication does not signify our approval to the exclusion of other products of suitable composition. 


\section{Perennials}

Weeds that require 3 or more years to complete their life cycles are considered perennials.

\section{Proper Management}

The first and best method of weed control begins with proper management practices that encourage a dense, thriving turf. Healthy turf shades the soil so sunlight can't reach weed seeds ready to germinate. A thick turf also minimizes the physical space available for weeds to become established. Several management practices promote a healthy, dense grass and help reduce the cost of weed control while maintaining the aesthetics of the lawn.

\section{Proper Turfgrass Selection}

The first management decision is selecting the best turf species or variety for a particular area. For example, moderately shaded areas support only a few turfgrass species. Growing bermudagrass or bahiagrass under any shade results in thin, weak turf that is very susceptible to weed invasion. Alternate grass choices for shady conditions include certain cultivars of St. Augustinegrass, zoysiagrass, and, to a lesser degree, centipedegrass. It is important to note that no grasses perform well in heavily shaded areas, and an alternative to turf, such as a groundcover, should be considered.

\section{Proper Cultural Practices}

Proper fertilization, watering, mowing, and pest control are required to produce a dense turf that can prevent weed infestation. If turf is over- or underwatered, over- or underfertilized, or mowed too low or too infrequently, the turf is weakened and the weeds move in. Sharpening the mower blades can reduce turf damage and the chances for weed invasion. It is very important to understand that weeds don't create a void; they fill a void.

\section{Traffic Control}

Turf damaged by foot or vehicle traffic invites weeds. Turf growing in soil compacted by excessive traffic, especially when the soil is saturated with water, cannot develop a healthy root system as well as it can under noncompacted soil conditions. Goosegrass, annual bluegrass, dollarweed, and certain sedges grow well in compacted and/or continuously wet soil. The first step to managing weeds in such a situation is to alleviate soil compaction and/or the saturated condition.

\section{Pest Control}

Pest damage makes the turf more susceptible to weed infestations by creating spaces for weed establishment and reducing the turf's competitive ability. Specifically, tunneling from mole crickets disrupts the soil surface, enabling weed seeds to readily germinate. Other insects and diseases can cause areas of turf to become bare. These open areas are usually slow to recover and enable weeds to become established and grow quickly. High nematode populations also thin the turf and make it less able to recuperate from environmental stresses. Weeds that often become established in nematode-infested soil include spotted spurge and Florida pusley.

\section{Sanitation}

It is extremely important to prevent the introduction of weeds into lawn areas. If one can prevent weed establishment, control practices are not necessary. Areas adjacent to turf areas that are hard to mow, such as fence rows or ditch banks, often support a weed population. These weeds normally produce seed that infests the nearby turf. These areas should also receive weed management attention.

Another good practice is to wash off mowers and trimmers used in weed-infested areas before mowing or trimming in weed-free areas. Similarly, rototillers should be thoroughly cleaned prior to and after use to minimize weed seed dispersal in the soil. Yard clippings that contain weeds should be properly disposed of or composted to reduce the possibility of contamination. These sanitation practices are also important to prevent the introduction of other turfgrass species, which might reduce the purity and quality of the lawn.

If construction or renovation is planned, it is important to use weed-free soil. When planting, use only certified seed or weed-free sod to minimize weed spread. It is not unreasonable to request a tour of the sod farm where the sod will be purchased in order to inspect grass quality.

\section{Weed Control}

\section{Methods}

As previously stated, it is essential to properly maintain turf to minimize weed invasion. If weeds become established, several methods of control are available.

Mowing - Many annual weeds can be eliminated if proper mowing height and frequency are maintained. Mowing prior to weed seedhead formation also reduces weed seed reserves. Some weeds, however, readily establish below 
the desired mowing height. Management of these weeds requires additional control methods. As a rule of thumb, when mowing, remove only a third of the turf's leaf blade at a time. This maintains a turf canopy that can grow vigorously while shading weeds and suppressing their growth.

Hand pulling or rogueing - If only a few weeds are present, it's simpler and less time-consuming to physically remove the plant, but if weeds are a major problem, other alternatives should be considered. When hand-pulling weeds, it is critical to remove the roots and underground parts to ensure the weeds will not survive and produce new shoots. Weeds such as Florida pusley and Virginia buttonweed might require the use of a small shovel to properly dig out the roots.

Smothering - Smothering with nonliving material to exclude light is effective in certain areas, such as flower beds, foot paths, or nurseries, where turf is not grown. Materials used for this include mulch, leaves, rocks, and plastic film. To be effective, a minimum of 2 inches is required when using natural mulch materials. As an alternative, synthetic mats impregnated with herbicides can be used. These provide long-term weed control when properly used, but care must be taken to minimize the risk of desirable plant roots encountering these layers.

Herbicides - An herbicide is any chemical that injures or kills a plant. Herbicides are safe and effective if product label instructions are followed. Label instructions include proper application timing, rates, and application methods. Herbicide application timing during the plant's growth cycle is important. For example, weeds not controlled prior to seedhead formation are harder to control and are able to deposit new seeds in future. Herbicides are classified based on how and when they control weeds.

\section{Herbicide Types}

Selective - A selective herbicide controls certain plant species (weeds) without seriously affecting the growth of other plant species (desired turfgrass). Most herbicides are selective herbicides. Herbicides are selected based on the turfgrass species (Table 1). This simplifies the application because the herbicide can be applied over the turf without injuring it.

Nonselective - Nonselective herbicides control green plants regardless of species. They are generally used to kill all plants, such as in the renovation or establishment of a new turf area, as a spot treatment, or to trim along sidewalks.
Glyphosate $\left(\right.$ Roundup $\left.^{\mathrm{Tn}}\right)$, glufosinate $\left(\right.$ Finale $\left.^{\mathrm{mm}}\right)$, and diquat $\left(\right.$ Reward $\left.^{\mathrm{Tx}}\right)$ are examples of nonselective herbicides. These herbicides injure turf. Therefore, in an established turf, their use is usually limited to spot applications for weedy patches, which must be followed by reseeding or resodding the treated area.

Contact - Contact herbicides affect only the portion of green plant tissue contacted by the herbicide spray. These herbicides are not translocated or moved in plants' vascular systems. Therefore, they do not kill underground plant parts, such as rhizomes or tubers. Repeat applications are often needed with contact herbicides to kill regrowth from these underground plant parts. Examples of contact herbicides include bentazon $\left(\right.$ Basagran $\left.^{\mathrm{Tm}}\right)$, glufosinate (Finale $\left.{ }^{\mathrm{Tm}}\right)$, and diquat $\left(\right.$ Reward $\left.^{\mathrm{TM}}\right)$.

Systemic - Systemic herbicides are translocated in the plant's vascular system. The vascular system transports the nutrients and water necessary for normal growth and development. Systemic herbicides generally are slower acting and kill plants over a period of days. Examples of systemic herbicides include glyphosate $\left(\right.$ Roundup $\left.^{\mathrm{TN}}\right)$, 2,4-D, dicamba $\left(\right.$ Banvel $\left.^{\mathrm{Ts}}\right)$, imazaquin (Image $\left.{ }^{\mathrm{Tm}}\right)$, and sethoxydim $\left(\right.$ Segment $\left.{ }^{\mathrm{Tx}}\right)$.

\section{Application Timing}

Two herbicide types, which differ based on application timing, are important in turfgrass weed management.

Preemergence - Preemergence herbicides form the basis for a chemical weed control program in turfgrasses and are used primarily to control annual grasses (e.g., crabgrass, goosegrass, and annual bluegrass) and certain annual broadleaf weeds (e.g., common chickweed, henbit, and lawn burweed). Preemergence herbicides are applied prior to weed seed germination. Knowledge of weed life cycles is important, especially when herbicide application is timed to attempt preemergence control. If the chemical is applied after weed emergence, preemergence herbicides have little or no effect. This narrow window of application timing is a potential disadvantage for many lawn care companies and homeowners, who often wait too late in the spring to apply the preemergence herbicide. A general rule of thumb for preemergence herbicide application is February 1 in South Florida, February 15 in Central Florida, and March 1 in North Florida, or before if day temperatures reach $65^{\circ} \mathrm{F}-$ $70^{\circ} \mathrm{F}$ for 4 or 5 consecutive days. These application timings generally coincide with blooming of landscape plants, such as azalea and dogwood. If goosegrass is the primary weed species expected, wait 3-4 weeks later than these suggested 
application dates, since goosegrass germinates later than most summer annual grasses.

For preemergence control of winter annual weeds such as annual bluegrass (Poa annua), apply an herbicide when nighttime temperatures drop to $55^{\circ} \mathrm{F}-60^{\circ} \mathrm{F}$ for several consecutive days (early October for North Florida; late October to early November for Central and South Florida).

Irrigation before and after application is necessary to activate most preemergence herbicides. Preemergence herbicides are generally effective in controlling weeds from 6-12 weeks following application. Most herbicides begin to degrade soon after application when exposed to the environment. Therefore, to obtain season-long control, an additional application should follow 6-9 weeks after the initial one.

Note: On those areas where turf is to be established (including sod and winter overseeded areas), most preemergence herbicides should not be used 2-4 months before planting. Otherwise, root damage and germination reduction of the turf seed may result.

Postemergence - Postemergence herbicides are active on emerged weeds. Weed size is very important for proper herbicide action. Generally, the younger the weed seedling, the easier it is to control. If the herbicides are sprayed when the weeds are mature, high rates are required for achieving control, which increases the risk of turf injury. Postemergence herbicide effectiveness is reduced when the weed is under drought stress, cold stress, has begun to produce seeds, or is mowed before the chemical has time to work (several days after application). Avoid application when these detrimental growing conditions exist.

\section{Fertilizer/Herbicide Mixtures}

Many herbicides are formulated with a fertilizer as the carrier. Fertilizer/herbicide mixtures allow a "weed-n-feed" treatment in the same application to the turfgrass. These materials should only be used when a lawn has a uniform weed population. If weeds exist only on a portion of the lawn, it may not be necessary to apply a "weed-n-feed" product to the entire lawn. If the situation warrants the use of a "weed-n-feed" product, it is important to determine if the manufacturer's recommended application rate supplies the amount of fertilizer needed by the turfgrass and the amount of herbicide required for weed control. Supplemental applications of fertilizer or herbicide may be required if the fertilizer/herbicide product does not supply enough fertilizer or herbicide to meet the fertility needs of the turfgrass or the amount of herbicide needed for weed control. Turfgrass fertilizer/herbicide products should be used with caution near ornamentals. Products containing dicamba, metsulfuron, or atrazine can be absorbed by the roots of ornamentals and cause severe injury. Do not apply products that contain these chemicals over the root zone of ornamental trees and shrubs.

\section{Adjuvants}

An adjuvant is a spray additive that enhances the performance or handling characteristic of an herbicide. Adjuvants include surfactants, crop oils, and crop oil concentrates, which if used indiscriminately may result in severe turfgrass injury or decreased herbicide performance. These additives do not improve the performance of preemergence herbicides and are used only with postemergence herbicides absorbed through the leaf. The herbicide label will indicate whether a spray additive is required.

\section{Weed Control Prior to Turf Establishment}

A nonselective herbicide should be used to kill existing weeds such as contaminant bermudagrass or nutsedge, which must be eradicated prior to grass establishment. These nonselective herbicides control only emerged plants. For best results, apply two treatments of a nonselective herbicide 14 days apart.

\section{Seeded Areas}

Do not apply preemergence herbicides prior to or immediately following seeding of grasses such as common bermudagrass, bahiagrass, centipedegrass, or ryegrass (winter overseed). Because of their root-pruning or seedling-kill modes of action, preemergence herbicides may be applied only after seeded grasses have emerged and are well established. A rule of thumb for timing is to make an application after the desired grasses are 2-3 inches tall or have begun to spread by runners (stolons). At this time, the preemergence herbicide may be applied at half the normal rate of application. Postemergence herbicides may also be applied at half the rate at the same growth stage.

If a preemergence herbicide has been applied, wait 9 weeks before attempting seeding. Use a small test area to determine when the herbicide residues permit seedling growth.

\section{Sprigged, Sodded, or Plugged Areas}

After planting, preemergence herbicides may be applied at half the normal rate recommended for established grasses 
following signs of new growth. Water should be applied immediately to the treated areas to activate the herbicide. If herbicide is not applied soon after planting, weed seedlings will emerge and will not be affected by preemergence herbicides. If over half the recommended herbicide rate is applied, root pruning may result to the turf.

Postemergence herbicides, in general, should not be applied until the grass is visibly growing and spreading. Mowing helps control most broadleaf weeds until the lawn is well established. Spot spraying of weeds should be practiced until establishment occurs.

\section{Weed Control in Established Turf}

\section{Preemergence Weed Control}

In established turfgrass, members of the dinitroaniline herbicide family (e.g., oryzalin [Surflan ${ }^{\mathrm{rx}}$ ], benefin and trifluralin [Team Pro $^{\mathrm{Tm}}{ }^{\mathrm{T}}$ ], prodiamine [Barricade ${ }^{\mathrm{Tm}}$ ], or pendimethaline $\left[\right.$ Pendulum ${ }^{\mathrm{Tw}}$, Pre-M] ${ }^{\mathrm{mm}}$ ) control annual grass and some broadleaf weed species when applied prior to weed seed germination. Bensulide (Bensumec ${ }^{\mathrm{Tm}}$ ) and dithiopyr $\left(\right.$ Dimension $^{\mathrm{Tx}}$ ) also provide preemergence annual grass and broadleaf control. Atrazine and isoxaben $\left(\right.$ Gallery $\left.^{\mathrm{Tm}}\right)$ primarily provide preemergence control of broadleaf weeds. All these herbicides must be activated with irrigation or moderate rain within 2 days after application so they will be in direct contact with the germinating seeds and emerging weed seedlings. If the soil is dry, their weed-killing effect is greatly limited. On the other hand, if the turf is overirrigated, most preemergence herbicides will be moved below the soil layer where the germinating weed seeds are, reducing weed control.

Broadleaf weed control - Broadleaf weeds in turf have traditionally been controlled with members of the phenoxy herbicide family (e.g., 2,4-D, MCPA, and mecoprop) and the benzoic acid herbicide family (e.g., dicamba). All are selective, systemic, foliar-applied herbicides; few broadleaf weeds, especially perennials, are controlled with just one of these materials. Therefore, these materials are commonly found in three-way herbicide mixtures, such as Trimec Southern $^{\mathrm{mm}}$, Ortho Weed-B-Gon MAX ${ }^{\mathrm{Tm}}$, and Spectracide Weed Stop for Lawns ${ }^{\mathrm{Tn}}$. Additionally, repeat applications spaced 10-14 days apart are usually necessary for satisfactory weed control.

Grass weed control - Postemergence control of grassy weeds is a major challenge because few products selective to the turf also kill this type of weed. For this reason, preemergence control is key for successful management of grassy weeds. However, a few alternatives can be used when postemergence control is necessary. In centipedegrass, grass weed control can be achieved with sethoxydim, an herbicide sold under the trade name Segment ${ }^{\mathrm{tm}}$. Additionally, atrazine-containing materials (e.g., Bonus $\mathrm{S}^{\mathrm{Tm}}$, Hi-Yield Atrazine Weed Killer, and Ortho's Weed B Gon ${ }^{\mathrm{Tm}}$ ) help control young grassy weeds with the added benefit of controlling many young broadleaf weeds in St. Augustinegrass and centipedegrass.

Nutsedge control - Yellow and purple nutsedge (often inappropriately called nut-grass) are the predominant nutsedge weed species in turfgrass. Other, more local members of the Cyperus genus include annual or water sedge, perennial and annual kyllinga, globe sedge, Texas sedge, flathead sedge, and cylindrical sedge. Path or slender rush, a member of the rush (Juncus) family, also can occur in some turf situations.

These weeds generally thrive in soils that remain wet for extended periods of time because of poor drainage or excessive irrigation. The first step in nutsedge control is to correct the cause of continuously wet sites. Do not overirrigate an area and, if necessary, provide surface and subsurface drainage.

Selective yellow nutsedge control is available with bentazon, an herbicide found in products such as Basagran $\mathrm{T} / \mathrm{O}^{\mathrm{Tm}}$. Bentazon is a contact material, meaning it controls only those portions of the weeds treated with it. Complete coverage of weeds is therefore necessary for greatest bentazon activity. Even with good herbicide coverage, regrowth normally occurs from the roots and tubers, and repeat applications are necessary.

Purple nutsedge can be controlled with herbicides containing either halosulfuron or imazaquin, sold as SedgeHammer $^{\mathrm{rm}}$ and Image ${ }^{\mathrm{rm}}$, respectively. As with bentazon, repeat applications-possibly over several years-are required to control all the underground reproductive parts of purple nutsedge. These herbicides also control other less-aggressive sedges (e.g., cocks-comb and green kyllinga, annual sedge), and they can be used in most warm-season turfgrass species.

\section{Application Procedures}

Proper rates - To avoid injury (e.g., yellowing, browning, stunting) to turfgrasses and ornamentals, apply the proper rate of herbicide. Mark off 1,000 square-foot areas to apply herbicides. Apply herbicides in $1 / 2-1$ gallon of water per 1,000 square feet (approximately 20-40 gallons per acre). 
Applicators - For increased application accuracy, air pressure-type sprayers are preferred over hose-end-type sprayers. For herbicides formulated as granulars, use a spreader and calibrate properly.

Vapor drift - Volatile vapor drift from 2,4-D esters or spray drift from 2,4-D amines, dicamba, or other phenoxy or benzoic acid compounds may damage sensitive plants such as ornamentals, trees, vegetables, or fruits. Amine forms of phenoxy herbicides can be used with greater safety near sensitive plants, but caution should still be exercised.

Equipment - Do not apply insecticides, fungicides, or other herbicides with equipment used for 2,4-D because it is difficult to remove this herbicide from most sprayers.

\section{General Pesticide Information}

Labels - Observe all directions, restrictions, and precautions on pesticide labels. It is dangerous, wasteful, and illegal to do otherwise. Pay special attention to the restricted-entry interval (REI) information. Home lawns have high traffic of children and pets, so it is important to make sure they do not enter the treated area during the REI. For some herbicides, the label specifies that the herbicide is not intended for use by homeowners. In those cases, a licensed pesticide applicator should spray the herbicide (Table 2).

Storage - Store pesticides behind locked doors in original containers with label intact, separate from seed and fertilizer.

Dosage - Use pesticides at correct dosage and intervals between applications to avoid illegal residues or injury to plants and animals.

Rinsing - Triple rinse a container that has been emptied into the spray tank. Never pour pesticides down a drain or into an area where humans, animals, or water could be exposed.

Disposal - Dispose of used containers in compliance with label directions to avoid water contamination and other hazards.

Clothing - Always wear protective clothing when applying pesticides. At a minimum, wear a long-sleeved shirt, long-legged pants, rubber gloves, boots, eye protection, and a wide-brimmed hat. Never go barefoot or wear sandals. Additional protective gear may be listed on the pesticide label.
Handling - Never eat, drink, or use tobacco products when handling pesticides, and always wash with soap and water after use. 
Table 1. Herbicide for homeowner lawn weed management

\begin{tabular}{|c|c|c|c|c|c|}
\hline & \multicolumn{5}{|c|}{ Lawn turfgrass } \\
\hline & Bahiagrass & Bermudagrass & Centipedegrass & St. Augustinegrass & Zoysiagrass \\
\hline Atrazine & No & No & Yes & Yes & Yes \\
\hline Benefin & Yes & Yes & Yes & Yes & Yes \\
\hline Benefin + trifluralin & Yes & Yes & Yes & Yes & Yes \\
\hline Bensulide & Yes & Yes & Yes & Yes & Yes \\
\hline Bentazon & Yes & Yes & Yes & Yes & Yes \\
\hline Carfentrazone & Yes & Yes & Yes & Yes & Yes \\
\hline Dicamba & Yes & Yes & Yes & Yes & Yes \\
\hline Dithiopyr & Yes & Yes & Yes & Yes & Yes \\
\hline Ethofumesate & No & No & No & Yes & No \\
\hline Fenoxaprop & No & No & No & No & Yes \\
\hline Halosulfuron & Yes & Yes & Yes & Yes & Yes \\
\hline Imazaquin & No & Yes & Yes & Yes & Yes \\
\hline Metolachlor & Yes & Yes & Yes & Yes & Yes \\
\hline Oryzalin & Yes & Yes & Yes & Yes & Yes \\
\hline Oxadiazon & No & Yes & No & Yes & Yes \\
\hline Pendimethalin & Yes & Yes & Yes & Yes & Yes \\
\hline Prodiamine & Yes & Yes & Yes & Yes & Yes \\
\hline Quinclorac & No & Yes & No & No & Yes \\
\hline Simazine & No & Yes & Yes & Yes & Yes \\
\hline $\begin{array}{l}\text { 2,4-D + dicamba + } \\
\text { MCPP, MCPA, and/or } \\
\text { 2,4-DP }\end{array}$ & Yes & Yes & Yes & No & Yes \\
\hline
\end{tabular}


Table 2. Examples of commercial products herbicides for home lawn weed management. ${ }^{1}$

\begin{tabular}{|c|c|}
\hline Herbicide common name & Example of brand name \\
\hline Atrazine & Many brands \\
\hline Benefin+trifluralin & $\begin{array}{l}\text { Team }^{\circledast} \text { Pro } \\
\text { Team }^{\circledast} 2 \mathrm{G}\end{array}$ \\
\hline Bensulide & $\begin{array}{c}\text { Bensumec } \\
\text { Weedgrass Preventer }\end{array}$ \\
\hline Bentazon & Basagran T/O \\
\hline Carfentrazone & Fertilome Weed Free Zone \\
\hline Dicamba & Banvel \\
\hline Dithiopyr & $\begin{array}{l}\text { Dimension* } \\
\text { Quali-Pro Dithiopyr* }\end{array}$ \\
\hline Ethofumesate & Prograss* \\
\hline Fenoxaprop & Acclaim Extra \\
\hline Fluazifop & Grass-B-Gon \\
\hline Halosulfuron & SedgeHammer \\
\hline Imazaquin & Image \\
\hline Metolachlor & Pennant Magnum* \\
\hline Oryzalin & Surflan \\
\hline Pendimethalin & $\begin{array}{c}\text { Pendulum } \\
\text { Pre-M } \\
\text { Halts Crabgrass Preventer }\end{array}$ \\
\hline Prodiamine & Barricade \\
\hline Quinclorac & $\begin{array}{c}\text { Drive } \\
\text { Fertilome Weed Out with Q }\end{array}$ \\
\hline Sethoxydim & $\begin{array}{c}\text { Segment } \\
\text { Fertilome Over-the-Top II Grass Killer }\end{array}$ \\
\hline Simazine & Princep \\
\hline 2,4-D + dicamba + MCPP, MCPA, and/or 2,4-DP & Many brands \\
\hline
\end{tabular}

